Marquette University

e-Publications@Marquette

Theology Faculty Research and Publications

Theology, Department of

9-1-2015

\title{
Peacemaking and Victory: Lessons from Kant's Cosmopolitanism
}

Philip J. Rossi

Marquette University, philip.rossi@marquette.edu

Accepted version. Philosophia, Vol. 43, No. 3 (September 2015): 747-757. DOI. (C) 2016 Springer International Publishing AG. Part of Springer Nature. Used with permission.

Shareable Link. Provided by the Springer Nature SharedIt content-sharing initiative. 
NOT THE PUBLISHED VERSION; this is the author's final, peer-reviewed manuscript. The published version may be accessed by following the link in the citation at the bottom of the page.

\title{
Peacemaking and Victory: Lessons from Kant's Cosmopolitanism
}

\author{
Philip J. Rossi \\ Theology Department, Marquette University \\ Milwaukee, WI
}

\begin{abstract}
In the texts in which Immanuel Kant discusses the principles governing international relations-including texts explicitly dealing with the sources leading states to armed conflict and the circumstances enabling its cessation-he does not directly engage the question "What constitutes victory in war?" This should not be surprising, given that Kant's treatment of war may be read as consonant with just war thinking for which victory seems an unproblematic concept Yet there are elements in the tone and the substance of his discussion that destabilize a placement of his views as unproblematically part of that tradition. The mordant tone of his dismissal of the Realpolitik guiding "political moralists" suggests a trenchant skepticism about almost any justification offered for leading a state into war. More substantively, an antinomy is at work in the contrast Kant makes, in the two sets of articles for perpetual peace, between a "state of nature" that, construed from the standpoint of the theoretical use of reason, defines the order of international relations as necessarily one of constant war, and the radical transformation of that order, enacted by moral reason in the definitive articles of perpetual peace, into a cosmopolitan order that heeds the categorical imperative "there shall be no war." In consequence, one may construct a Kantian answer to the question "What constitutes victory in war?" by framing it in reference to this cosmopolitan hope for an international order

[Citation Journal/Monograph Title, Vol XX, No. XX (m yyyy): pg. XX-XX. DOI. This article is @ [Publisher's Name] and permission has been granted for this version to appear in e-Publications@Marquette. [Publisher's Name] does not grant permission for this article to be further copied/distributed or hosted elsewhere without the express permission from [Publisher's Name].]
\end{abstract}


NOT THE PUBLISHED VERSION; this is the author's final, peer-reviewed manuscript. The published version may be accessed by following the link in the citation at the bottom of the page.

securing enduring peace. Within the moral horizon of cosmopolitan hope, victory in war-like war itself-is unmasked as morally unintelligible.

Keywords: Victory; War; Perpetual peace; Kant; Categorical imperative; Practical reason

In the various texts in which he discusses the principles that should govern relations among nations, including the texts in which he explicitly deals with the circumstances and the motivations that lead states to engage one another in armed conflict and the circumstances that enable its cessation, Immanuel Kant does not directly engage the question "What constitutes victory in war?"1 This should not be all that surprising: There is much in Kant's account of war as ingredient in the dynamics of the political order of sovereign states and in his proposal for instituting a federation of states as the basis for an international order conducive to the securing of perpetual peace that can be read as consonant with the main elements of "just war" thinking, for which victory has not ordinarily loomed as a problematic concept.

Yet beneath what initially looks like an unremarkable endorsement of the just war principles that in Kant's time were already emerging as a substantive moral point of reference for international law, there are elements in both the tone and the substance of his discussion that destabilize too easily placing his views as unproblematically part of that tradition. The tone of mordant irony that, in Perpetual Peace, pervades his treatment of war, most notably in his treatment of the "principles" by which "political moralists" justify the use of force as an instrument of policy in an international order that they view as Hobbes's "state of nature" writ large, manifests a trenchant skepticism about almost any justification offered for leading a state into war. $\stackrel{2}{ }$ More substantively, there is also a destabilizing complexity to the conceptual landscape of international conflict and its resolution that he maps in the arguments put forth in Perpetual Peace and which are complemented by discussions in other texts, such as The Metaphysics of Morals, Religion within the Boundaries of Mere Reason, the second essay in The Conflict of the Faculties, and the third part of the essay "Theory and Practice."

This complexity arises not simply from the challenge of attempting to articulate an account of Kant's definitive view of the moral status of war from a set of texts, published between 1784 and

[Citation Journal/Monograph Title, Vol XX, No. XX (m yyyy): pg. XX-XX. DOI. This article is (C) [Publisher's Name] and permission has been granted for this version to appear in e-Publications@Marquette. [Publisher's Name] does not grant permission for this article to be further copied/distributed or hosted elsewhere without the express permission from [Publisher's Name].] 
1798, that give evidence of shifts and developments in his thinking. 3 It also arises from the tensions built into fundamental structure of his overall critical philosophy. This tension has its specific locus in the "two standpoints," the theoretical and the practical, that he takes to be necessarily embedded in the uses of human finite reason as it seeks to render intelligible our human engagement with the world. ${ }^{4}$ Even as Kant resolutely maintains that these standpoints function within the unity of one and the same reason, this does not prevent him from unflinching recognition that, to the extent that human reason remains uncritical, i.e., undisciplined by a consciously appropriated awareness of the limits set by reason's finitude, these two standpoints will present themselves to us in the form of seemingly irreconcilable antinomies for our efforts to render the world intelligible.

For Kant, human reason's drive to "make sense of" what it is to be human, provides the fundamental thrust and trajectory to his critical project. Kant argues that antinomies arise within this drive to make sense of the human when human reason steps beyond the limits that constrain its legitimate exercise for theoretical cognition to the conditions of space and time, which provide parameters for the causal necessity that renders intelligible the empirical workings of world. In stepping beyond those limits, theoretical reason ventures into a field in which intelligibility is not a function of causal necessity but a function rather of the agential freedom for determining ends that Kant calls moral autonomy. This field is properly the domain for the exercise of the practical use of reason. Kant further argues that, relative to each other, it is the practical use of reason that has primacy above its theoretical use with respect to the overarching "interest" of reason in rendering intelligible the human place in the cosmos. Within this framework, antinomies can thus be seen to arise in consequence of giving unreflective primacy to the empirical intelligibility arising from the theoretical use of reason in place of the reflective moral primacy that arises from the enactments of the practical use of reason. Once such antinomies are recognized, they can then be resolved by an effective recognition of the primacy of reason's moral use.

It may initially seem that the overarching issue of the unity of a human reason that functions both theoretically and practically within the structure of Kant's critical enterprise may have little direct bearing upon constructing a plausible Kantian response to the specific question permission has been granted for this version to appear in e-Publications@Marquette. [Publisher's Name] does not grant permission for this article to be further copied/distributed or hosted elsewhere without the express permission from [Publisher's Name].] 
"What does it meant to win a war?" let alone upon resolving the thorny questions raised by his proposals for an international cosmopolitan order that envisions the cessation of war as its moral outcome. My argument in this essay, nonetheless, will begin from a suggestion that we can, in fact, locate such an antinomy at work in Kant's account of the moral dynamics by which human moral agency is empowered to transform what appears to be the (theoretical) inevitability of war within an international "state of nature" into the moral possibility of establishing a world order for enduring peace. My suggestion is that this antinomy functions specifically in the relationship between what he calls the "preliminary" and the "definitive" articles for perpetual peace. This relationship, particularly with respect to the mode of transition from the former to the latter, is not fully articulated in Kant's text; my proposal is that, given the larger framework of Kant's understanding of the workings of reason, we attempt to read this relationship in terms of the dynamics of the tension between the two standpoints of human finite reason, theoretical and practical, that give rise to the antinomies that mark human reason's "peculiar fate" in the absence of the discipline of self-limitation he terms "critique."

Within this reading, the intelligibility of the "preliminary" articles stands within the ambit of a theoretical standpoint for which war is a necessary and inevitable outcome of a lawless "state of nature" among sovereign nations; the intelligibility of the "definitive articles," in contrast, arises from the standpoint of the exercise and the primacy of practical (moral) reason, for which the definitive cessation of war is a possibility that human agency is called upon to effect in response to the categorical imperative "there shall be no war." $\underline{6}$ This moral possibility for the definitive cessation of war is one that stands beyond the ambit of the intelligibility provided by the theoretical standpoint, in that both its intelligibility and its enactment are mutually a function of human moral freedom, exercised as the practical use of reason, not the outcome of the inexorable casual workings of the world that are decipherable by reason's theoretical use.

How, then, does this account of the origin and resolution of such antinomies help to articulate the relationship between the "preliminary" and the "definitive" articles that Kant proposes in Perpetual Peace? The answer to this question lies, I suggest, in coordinating the distinction between these articles with the distinction 
Kant makes between "the moral politician" and the "political moralist" in the first Appendix in the essay. The preliminary articles are preliminary inasmuch as-in the absence of the effective enactment of the definitive articles - their intelligibility can be rendered adequately in terms of the theoretical use of reason. They can all be adopted on the basis of a calculating political prudence-such as that used by the "political moralist" - in which each state continues to reserve the possibility of making its own interest ultimately and solely decisive. The resolution of this antinomy depends upon an acknowledgment of primacy of reason's moral use; in this case, it is "moral politician," not the "political moralist," who is in a position to make such an acknowledgment. Such acknowledgment consists in giving decisive weight to the categorical imperative, "there shall be no war," and it is only in virtue of such an acknowledgment that the transition from the first to the second set of articles can be concretely navigated by sovereign nations. Only moral, not prudential, grounds stand sufficient for establishing the enduring peace that definitively enacts the categorical imperative "there shall be no war."

In consequence, the contrast Kant draws between the "moral politician" and the "political moralist" is crucial to the resolution of this antinomy, inasmuch as only the former stands ready to enact the primacy of moral reason in the concrete exercise of the political judgments needed to bring the definitive articles into effect. The substance and the tone of Kant's dismissal of the Realpolitik that guides "political moralists" even as they pay lip service to principles of constitutional law and international order is thus one marker of the tension of this underlying antinomy. This antinomy lies between a "state of nature" that, as construed from the standpoint of the theoretical use of reason, defines the extant order of international relations as necessarily and evermore one of constant war, and the radical transformation of that order, enacted by the exercise of moral reason in the definitive articles for perpetual peace, into a cosmopolitan order that heeds the categorical imperative "there shall be no war." In the first, "it is absolutely clear that the right to go to war surfaces only in the tense and unstable condition of the absence of the full recognition of law amongst states...it is simply a right in the absence of right" (Williams 2012); in the second, the transformation of that order is such that it provides "conditions under which states would come to abandon war altogether as the means for settling disputes permission has been granted for this version to appear in e-Publications@Marquette. [Publisher's Name] does not grant permission for this article to be further copied/distributed or hosted elsewhere without the express permission from [Publisher's Name].] 
about their rights" (Covell 1998). Within this context, it may not be far-fetched to suggest that the transition from the preliminary to the definitive articles has a precondition that human beings as political agents and actors undergo "a revolution in the disposition of [their] human being" that is the counterpart of the "revolution" that Kant sees requisite for each human moral agent's overcoming of "radical evil". $\underline{\underline{ }}$ In other words, the "political moralist" needs to be moved to undertake a moral transformation that will make her a "moral politician."

Taken together, these elements suggest the presence of a trajectory in Kant's thinking about war that stands athwart just war thinking, a trajectory that arises from his account of the principles of human moral self-governance (i.e., autonomy) that are operative in the practical use of reason. This trajectory, moreover, is one that provides a fundamental orientation for Kant's understanding of the responsibility human agents have, as autonomous participants in the shaping of history, for establishing, through the exercise of practical reason, the social, political, and cultural conditions of a cosmopolitan international order that will make it possible to bring about lasting peace among nations. It will be this cosmopolitan trajectory of enacting the primacy of practical reason in history that provides the basis for what I will argue may be appropriately called a Kantian moral "deconstruction" of the concept of "victory" in its common usage in political, military, and diplomatic discourse to mark the cessation of combat that ensues upon the military and political capitulation of one side to the other.

In order to set out the contours of such a Kantian "deconstruction" it will be useful first to note that this cosmopolitan trajectory toward the historical enactment of the primacy of practical reason suggests that any endorsement that Kant makes of just war principles is, at best, a function of what he sees as only provisional steps within the working of human history in the direction of the establishment of an international order that will provide definitive conditions for securing perpetual peace. $\underline{8}$ Prior to the establishment of those conditions, wars-and, consequently, the characterization of victory in a war-occur as (and have their theoretical intelligibility as) events that are woven into the conflictual fabric of human social interaction in history. According to Kant's account of these provisional

[Citation Journal/Monograph Title, Vol XX, No. XX (m yyyy): pg. XX-XX. DOI. This article is (C [Publisher's Name] and permission has been granted for this version to appear in e-Publications@Marquette. [Publisher's Name] does not grant permission for this article to be further copied/distributed or hosted elsewhere without the express permission from [Publisher's Name].] 
steps, humans first find themselves in a (juridical) "state of nature" that is marked by contention with one another. It should be noted that Kant's account of this state of nature as a "state of externally lawless freedom" anthropological presuppositions embedded in the Hobbesian rendering of this state of as bellum omnium contra omnes. Even so, Kant does take emulation, competition, and invidious comparison, which he emblematically renders as "unsocial sociability," to be a social dynamic powerful enough regularly to bring about conflicts that require external constraint for their resolution. Although these are conflicts between individuals, not states, Kant does not hesitate to name them "war." Bringing these conflicts to an end requires bringing individuals, coercively if necessary, into the civil order of a particular state that, by framing laws according to the "principle of right," 10 provides enforceable rules for the external governance of the mutual exercise of human freedom in order to limit and adjudicate such conflicts. One consequence is that what might have been considered the "victory" of one party over another in the context of physical contention in the state of nature, is now transposed into an adjudicatory context of a court of law in which a third party with civil jurisdiction determines the outcome.

Bringing individuals into a "juridico-civil" state is thus just the initial stage in Kant's account of the steps that lead to the establishment of the social conditions under which it become possible for the exercise of human practical reason to be an effective agency in the establishment of the cosmopolitan world order to bring about the perpetual peace that Kant considers the "highest political good" for humanity. $\underline{11}$ The civil order that a state establishes to bring individuals out of state of nature in which civil adjudication replaces physical contention among those individuals does not, however, also provide conditions that are sufficient to resolve conflicts that arise between and among states. In fact, Kant considers the condition that exists among the various juridico-civil states to constitute an international state of nature in which war is the default position. This international state of nature is one that he describes as significantly more challenging to alter than the one that existed between individuals prior to the establishment of civil society. This is so because he sees no authority higher than that of the sovereignty of each individual state that could legitimate the coercive means that would be needed to permission has been granted for this version to appear in e-Publications@Marquette. [Publisher's Name] does not grant permission for this article to be further copied/distributed or hosted elsewhere without the express permission from [Publisher's Name].] 
bring states together into the international counterpart of a juridicocivil state. $\underline{12}$ As a result the fundamental "right" that nations exercise within this condition can be nothing other than a "right of war":

The public right of states (jus publicum civitatum) in their relations to one another is what we have to consider under the designation of the "Right of Nations." Wherever a state, viewed as a moral person, acts in relation to another existing in the condition of natural freedom, and consequently in a state of continual war, such right takes it rise. $\underline{13}$

Within this condition of an international state of nature, "victory" in a particular war between contending states becomes an outcome that has an inherent instability to it. Kant understands the dynamics at work between nations in this condition to be such that both victors and vanquished, in the absence of any constraining force, will, upon agreement to a treaty concluding the current war, immediately begin to take preparatory steps for resuming armed hostilities, if not with one another, then with some other state considered ripe for confrontation and conquest. What Kant calls the Preliminary Articles for perpetual peace thus do not address themselves directly to this baseline condition of international lawlessness; they are proposed primarily in the hope that their acceptance will then make possible the further steps required, under the Definitive Articles, for nations to exit from this condition. $\frac{14}{}$ The preliminary steps thus function as precepts which accord with a prudential judgment that bears upon each state's assessment of what is efficacious for its self-interest. Unlike the Definitive Articles, however, they do not arise in function of the hope for moral efficacy in establishing conditions for perpetual peace that the exercise of practical reason makes possible in providing a cosmopolitan perspective upon the historical trajectory of human action. Put in terms of the antinomy that structures their relation, the theoretical intelligibility of the Preliminary Articles, while sufficient to provide precepts for prudential calculation of policies that serve a state's interest, any or all of which may be in accord with moral principles, does not provide those articles-let alone the Definitive Articles-with an adequate and appropriate moral intelligibility. The requisite moral intelligibility can only be provided in function of the acknowledgment of the primacy of practical reason, an 
acknowledgment that is performed in the recognition and enactment of the categorical imperative "there shall be no war."

There thus are elements in Kant's presentation of these preliminary articles that, even in view of their primarily theoretical and prudential character, can be construed to bear upon the question of what constitutes victory. Of most general significance in this regard is that these six articles presuppose the continuing operation of the conflictual dynamics of the international state of nature. Under these articles, the basic structural circumstances of the "international state of nature"-i.e., individual sovereign states "independent of external laws"15_-remain in place, including its motivational dynamics of prudently exercised and theoretically justified national self-interest.

The articles are framed to regulate a set of conditions likely to bring on new (or renewed) armed hostilities, but they do not aim at altering the fundamental conditions of the international state of nature; in consequence, the arguments Kant offers on their behalf do not directly appeal, as do the arguments he offers for the Definitive Articles, to the self-governing moral freedom (autonomy) that is the most basic of Kant's moral principles. His arguments for the preliminary articles are thus couched in terms that, even as they reference important moral considerations, also recognize the decisive operative weight that that pragmatic and prudential considerations of national interest continue to play in the international state of nature, even with the adoption of these preliminary articles.

Of specific note with respect to the significance and meaning of "victory," moreover, is the first article, "No Treaty of Peace Shall Be Held Valid in Which There Is Tacitly Reserved Matter for a Future War," that bears directly upon the possibility and effectiveness of peace treaties, which are presumed to be the instruments that formalize terms of victory and defeat. Kant remarks that, in the absence of the first article, "a treaty would be only a truce, a suspension of hostilities." 16 Yet Kant does not then conclude that a peace treaty that observes the terms of this first article would thereby have the effect of securing lasting peace. Rather, any "victory" that is secured in a such peace treaty, even if it is a settlement reached after an (ex hypothesi) justly declared war that is both waged justly and then meets the conditions for what Kant considers a just mode for its termination, still stands within the ambit of an international order that, even under the

[Citation Journal/Monograph Title, Vol XX, No. XX (m yyyy): pg. XX-XX. DOI. This article is @ [Publisher's Name] and permission has been granted for this version to appear in e-Publications@Marquette. [Publisher's Name] does not grant permission for this article to be further copied/distributed or hosted elsewhere without the express permission from [Publisher's Name].] 
Preliminary Articles, remains "only the negative surrogate of an alliance that averts war"17 in which no such "victory" can stand as definitive. $\underline{18}$

This point is of direct significance for engaging Kant's account with the question "What does it mean to win a war?" Kant's attribution of a provisional status to "victory," so long as the international state of nature obtains, is a function of the way he places his understanding of the moral status and historical significance of war and, a fortiori, of victory in war, within the larger lineaments of his account of human moral life. In that account, the standpoint that the practical (moral) use of our human reason enables us to take upon the trajectory of humanity's moral vocation in history toward securing lasting peace is central to Kant's analysis and assessment of the politics and the morality of war and its outcomes. I will thus propose that we turn again to situating Kant's discussions of war within that larger context of the practical use of our human reason, which provides the basis from which to elaborate what amounts to Kant's deconstruction of "victory" in war, particular with respect to any substantive moral weight that we might be tempted to attach to this concept. Central to that deconstruction will be the conceptual coordinates provided by Kant's account of the cosmopolitan perspective that moral reason enables us to take upon the workings of history and upon the outcome of human action as ingredient in giving shape and direction to history. $\underline{19}$ These coordinates are central to articulating the import of the structural framework of national and international governance that the three Definitive Articles propose as the catalyst for transforming the international state of nature into a cosmopolitan world order in which, because there are no wars, "victory" has ceased to be a functioning concept in the discourse of international relations.

The main coordinates will be provided, not surprisingly, by the taxonomy according to which Kant takes human finite reason to function as the principle for the two fundamental ways, i.e., by our thinking and by our action, in which we address the challenge to make sense of the world. In Kant's terminology, one way, the way of thinking, is exhibited in the speculative (theoretical) use of our reason, the other way, the way of action, is exhibited in the practical (moral) use of our reason. Kant further posits that, even though these ways are irreducible to one another, they stem from a single source, the permission has been granted for this version to appear in e-Publications@Marquette. [Publisher's Name] does not grant permission for this article to be further copied/distributed or hosted elsewhere without the express permission from [Publisher's Name].] 
dynamism of our reason (which he terms the "interest of reason") to render intelligible, both for our thinking and for our acting, the world we engage and our human place in that world. Kant elaborates this taxonomy in his three major works of "critique"-the Critique of Pure Reason, the Critique of Practical Reason, and the Critique of Judgment-published between 1781 and 1790. Although a key aspect of the taxonomy he enunciates in those works is the primacy that he assigns to the workings of the practical (moral) use of reason, there are important implications of that primacy that emerge with full force and clarity only in texts that have often been relegated by later commentators to peripheral status relative to the three Critiques. These texts include a number of the occasional essays on culture, history, and politics that he published beginning in the mid-1780s as well as major texts from the 1790 s such as Religion within the Boundaries of mere Reason and The Metaphysics of Morals. A particularly important set of implications that emerge in these later writings help to articulate the role that the practical use of reason takes in shaping the socio-cultural, historical, and political contours of humanity's world to accord with what Kant calls a "cosmopolitan point of view."

Within Kant's taxonomy of reason, the perspective that exhibits the theoretical use of reason takes the array of socio-cultural and political dynamics constituting human history as the outcome of forces functioning in modes of natural causality that proceed on a course indifferent to individual and collective human intentionality and purposes. This perspective takes the outcome and direction of history to issue from the intersection of contingent causal processes within which free human determination of action has no distinctive place; human action in and upon history is, at best, simply one other causal process at work in a field that has no overarching inner directionality, save that which issues from the intersecting vectors of those causal processes, including those intertwined with the promotion of the selfinterest that is a natural function of human inclinations. From such a perspective, we stand as spectators before whom events unfold from dynamisms upon which we have no distinctive point of purchase. Such a theoretical perspective comports well with the dynamisms that Kant describes functioning within the international state of nature. Their inevitable outcome is a constant state of war and of preparation for permission has been granted for this version to appear in e-Publications@Marquette. [Publisher's Name] does not grant permission for this article to be further copied/distributed or hosted elsewhere without the express permission from [Publisher's Name].] 
war in which the single operative "right" that can function as "a law of nations" is a "right to war."

Kant's description of these dynamics, especially in Perpetual Peace, is cast in ironic tone that occasionally sounds a sardonic note. After noting that the "concept of a law of nations as a right to make war does not really mean anything" he adds "[t]he only conceivable meaning of such a law of nations might be that it serves men right who are so inclined that they should destroy each other and thus find perpetual peace in the vast grave that swallows both the atrocities and their perpetrators." $\underline{20}$ While there is a Hobbesian resonance to this remark, Kant does not offer it in support of resignation to the continuance of the international order as a "state of nature" in which war is the constant and inevitable outcome. This remark enunciates, instead, a mordant counterpoint to the cosmopolitan perspective, which on Kant's account makes possible a transformative reconceptualization of "the law of nations" into an order of hospitality that will radically undermine any moral legitimacy to the possibility of war. What thus had been the sole international right of the law of nations in an international state of nature, i.e., the "right to make war," is superseded in a cosmopolitan world order by "the right to cosmopolitan hospitality." $\underline{21}$

The basis on which Kant proposes such a radical reconstitution of international order is moral, rather than prudential. This basis is found the practical (moral) exercise of our reason, inasmuch as it pronounces-and human moral agents heed-its "irresistible veto 'there is to be no war.'"22 Heeding that injunction of reason as a categorical imperative makes possible the cosmopolitan hope, validated in the exercise of moral reason, that human efforts can be effective in establishing conditions for lasting peace. Such cosmopolitan hope, moreover, is social: it provides agents with a way to envision the exercise of their freedom not simply as it bears upon their own individual moral destiny but also upon the social outcomes of history and culture. $\frac{23}{1}$ It thereby enables them to envision the highest good attained through human freedom to pertain to humanity as a whole, to humanity as a socially and historically situated species, not merely to individual human agents. $\underline{24}$ permission has been granted for this version to appear in e-Publications@Marquette. [Publisher's Name] does not grant permission for this article to be further copied/distributed or hosted elsewhere without the express permission from [Publisher's Name].] 
What bearing does this then have on the prospect of framing a plausible Kantian answer to the question "What constitutes victory in war?" The fundamental import of placing the question about the meaning of victory within the horizon of a cosmopolitan hope is that it indicates that such an answer would be most appropriately framed in reference the establishment of an international order for enduring peace secured within the moral horizon of the Definitive Articles, rather than within the theoretical and prudential horizon offered in the Preliminary Articles. As a result, Kant's answer would thus not be referenced to "just war" principles that seem to remain operative under the Preliminary Articles. Within the prudential horizon of those articles, victory bears only the conventional, prudential meaning of the cessation of hostilities by the military and political capitulation of one of the parties to the armed conflict. In contrast, when "victory" is instead viewed within the horizon of the moral possibility for the end of war that is provided by a cosmopolitan hope in the efficacy of human action for securing perpetual peace, it undergoes a definitive moral deconstruction. As it does to war itself, a cosmopolitan perspective unmasks victory in war as morally unintelligible.

\section{References}

Covell, C. (1998). Kant and the law of peace: A study in the philosophy of international law and international relations (p. 123). Basingstoke and London: Macmillan.CrossRefGoogle Scholar

Easley, E. S. (2004). The war over perpetual peace: An exploration into the history of a foundational international text. New York: Palgrave Macmillan.CrossRefGoogle Scholar

Kleingeld, P. (2012). Kant and cosmopolitanism: The philosophical ideal of world citizenship. Cambridge: Cambridge University Press. Google Scholar

Mertens, T. (2012). Kant and the just war tradition. In W. A. Barbieri Jr. \& H.G. Justenhoven (Eds.), From just war to modern peace ethics (pp. 231-247). Berlin: De Gruyter.Google Scholar

Neiman, S. (1994). The unity of reason: Rereading Kant. Oxford/New York: Oxford University Press.Google Scholar

Rossi, P. J. (2008). Cosmopolitanism and the interests of reason: A social framework for human action in history. In V. Rohden et al. (Eds.), Recht und Frieden in der Philosophie Kants: Akten des $X$. Internationalen Kant-Kongresses, Vol. 4 (pp. 65-75). Berlin: Walter de Gruyter.CrossRefGoogle Scholar

[Citation Journal/Monograph Title, Vol XX, No. XX (m yyyy): pg. XX-XX. DOI. This article is @ [Publisher's Name] and permission has been granted for this version to appear in e-Publications@Marquette. [Publisher's Name] does not grant permission for this article to be further copied/distributed or hosted elsewhere without the express permission from [Publisher's Name].] 
NOT THE PUBLISHED VERSION; this is the author's final, peer-reviewed manuscript. The published version may be accessed by following the link in the citation at the bottom of the page.

Rossi, P. J. (2013). Cosmopolitanism: Kant's social anthropology of hope. In S. Bacin et al. (Eds.), Kant und die Philosophie in weltbürgerlicher Absicht: Akten des XI. Kant-Kongresses 2010, Bd. 4 (pp. 827-837). Berlin: Walter de Gruyter.Google Scholar

Williams, H. (2012). Kant and the end of war: A critique of just war theory (pp. 85-86). New York: Palgrave Macmillan.CrossRefGoogle Scholar

\section{Notes}

${ }^{1}$ Among the key texts dealing with war are "Idea for a Universal History from a Cosmopolitan Point of View" (1784), "On the Common Saying: That May Be Correct in Theory, but It Is of no Use in Practice" (1793), Perpetual Peace (1795), The Metaphysics of Morals; The Doctrine of Right (1797), and "An Old Question Raised Again: Is the Human Race Constantly Progressing?" (1798). Page references to Kant's text are to appropriate volume and page numbers in the standard German critical edition of his works, Kants Gesammelte Schriften, Bd 1-22 hrsg. von der Preussischen Akademie der Wissenschaften (1900-), usually referenced as the Akademie-Ausgabe (AA), and currently published by De Gruyter, Berlin. Page references to the Critique of Pure Reason are to the original pagination of the 1st (A) and the 2 nd (B) editions of the Critique. English translations are from the appropriate volume of The Cambridge Edition of the Works of Immanuel Kant, ed. Paul Guyer and Allen W. Wood (Cambridge: Cambridge University Press: 1995-).

2 Most notably in Perpetual Peace, Appendix I: On the Opposition between Morality and Politics with Respect to Perpetual Peace. He draws a distinction in this section between the "moral politician...who so chooses political principles that they are consistent with those of morality" and the "political moralist...who forges a morality in such a way that it conforms to the statesman's advantage" (AA 8:372).

${ }^{3}$ It may be useful to note that this essay does not claim to present Kant's "definitive view" about what constitutes victory in war, especially since it is a question he neither frames nor explicitly addresses. This essay presents, instead, an exploration of consequences for Kant's account of war and the place of "victory" in war that would follow from giving interpretive primacy to the most fundamental moral claim he makes with respect to war. That claim is that "there shall be no war" is a categorical imperative to be constantly heeded by the human moral subjects whose agency gives human society its concrete historical shape.

4 This reading of the "two standpoints" is part of a larger interpretive account of Kant's critical project in which the fundamental dynamic of human

[Citation Journal/Monograph Title, Vol XX, No. XX (m yyyy): pg. XX-XX. DOI. This article is @ [Publisher's Name] and permission has been granted for this version to appear in e-Publications@Marquette. [Publisher's Name] does not grant permission for this article to be further copied/distributed or hosted elsewhere without the express permission from [Publisher's Name].] 
NOT THE PUBLISHED VERSION; this is the author's final, peer-reviewed manuscript. The published version may be accessed by following the link in the citation at the bottom of the page.

reason is construed in anthropological terms: human finite reason is constituted by a drive to render intelligible, to "make sense of," what it is to be human. A provocative discussion of this anthropological thrust in the critical enterprise can be found in Neiman (1994), Chapter 5, "The Task of Philosophy," 185-206.

${ }^{5}$ Kant speaks of reason's "peculiar fate" in the first sentence of the Preface to the 1st edition of the Critique of Pure Reason, A vii.

6 Two key passages in which Kant identifies "there shall be no war" as a categorical imperative are found in Perpetual Peace (AA 8: 355-356) and The Metaphysics of Morals (AA 6: 354-355).

7 Religion within the Boundaries of Mere Reason, AA 6: 47.

${ }^{8}$ See Mertens (2012) for a probing criticism of efforts that have been made to place Kant squarely within the traditions of just war thinking. A more extensive treatment of Kant's relationship to just war thinking that also disputes his placement within that tradition is Howard Williams, Kant and the End of War: A Critique of Just War Theory. Williams notes at the outset (p. 3) that "one of [his] major concerns is to reestablish Kant's reputation as a critic of just war thinking."

9 The Metaphysics of Morals: Doctrine of Right §42, "The Postulate of Public Right" (AA 6: 307-308).

10 This principle, as enunciated in The Metaphysics of Morals is: "Every action is right which in itself, or in the maxim on which it proceeds, is such that it can co-exist along with the freedom of the will of each and all inaction, according to a universal law" (AA 6: 230).

11 The Metaphysics of Morals: Doctrine of Right, Conclusion (AA 6: 355).

12 There has been a long standing discussion among commentators about whether Kant takes the definitive form of the relation among states needed to provide conditions for perpetual peace to be a confederation in which individuals states retain sovereignty or a single world state. One recent attempt to chart the varied readings that Kant's views have been given from the mid-nineteenth century onward is Easley (2004). Kleingeld (2012), Chapter 3, "Kant and Cloots on global peace," 4071 , provides a useful account of the development of Kant's thinking on this point.

13 Metaphysics of Morals, §53, AA 6: 343.

${ }^{14}$ My discussion here elides over a significant question about the relationship between Kant's presentation of two sets of "Articles" for perpetual peace in his 1795 essay and his later, condensed presentation of 1797 in $\S 61$ of The Metaphysics of Morals: The Doctrine of Right (AA 6: 350-351) of his proposal for a permanent congress of nations as the vehicle for perpetual peace in which there is no mention of "preliminary articles." Williams, Kant and the End of War, extensively

[Citation Journal/Monograph Title, Vol XX, No. XX (m yyyy): pg. XX-XX. DOI. This article is @ [Publisher's Name] and permission has been granted for this version to appear in e-Publications@Marquette. [Publisher's Name] does not grant permission for this article to be further copied/distributed or hosted elsewhere without the express permission from [Publisher's Name].] 
NOT THE PUBLISHED VERSION; this is the author's final, peer-reviewed manuscript. The published version may be accessed by following the link in the citation at the bottom of the page.

discusses the overlap and the differences between these two texts in Chapters 2-5, 40-112.

15 Perpetual Peace, AA 8: 354.

16 Perpetual Peace, AA 8: 343.

17 Perpetual Peace, AA 8: 357.

${ }^{18}$ A crucial difference between the two sets of articles-though one that Kant does not explicitly state-is that compliance with all (or any) of the preliminary articles does not require that the state that agrees to them has a republican form of polity. The importance of this difference for the transformational character of the definitive articles is underscored, I believe, by the fact that the first of the Definitive Articles is: "The Civil Constitution of Every State Should Be Republican" (AA 8: 349).

19 For further discussion of Kant's cosmopolitanism as a practical (moral) perspective on the efficacy of human action in history see, Rossi (2008, 2013).

${ }^{20} A A$ 8: 357. The play on the word "right" is in the original; the vast grave is an allusion back to the image with which Kant begins the essay: a graveyard that a Dutch innkeeper used on the sign for his establishment (AA 8: 343).

${ }^{21}$ The Metaphysics of Morals: The Doctrine of Right, §62 (AA 6: 352-353).

22 AA 6: 354.

23 To the extent that Kant's account invests the agency of the state in respect to the international order in the sovereign ruler, it is the sovereign who then has primary responsibility for a social envisioning that accords with the moral hope that a cosmopolitan perspective offers. This is one of the features of Perpetual Peace that suggests that a key part of the audience for this essay that Kant had in view were the monarchs of Europe, perhaps in the hope of inviting their transformation from "political moralists" into "moral politicians."

24 To the extent that the highest good, as it pertains to individuals, consists in forming a "good will," it may be construed, as G. Felicitas Munzel argues in Kant's Conception of Moral Character (Chicago: University of Chicago Press, 1999), to be the shaping of one's good moral character.

[Citation Journal/Monograph Title, Vol XX, No. XX (m yyyy): pg. XX-XX. DOI. This article is @ [Publisher's Name] and permission has been granted for this version to appear in e-Publications@Marquette. [Publisher's Name] does not grant permission for this article to be further copied/distributed or hosted elsewhere without the express permission from [Publisher's Name].] 